\title{
PELATIHAN STRATEGI PEMASARAN ONLINE DALAM RANGKA OPTIMALISASI PEMASARAN PRODUK KHAS TEMIYANG
}

\author{
Yolla Margaretha ${ }^{1}$, Asni Harianti ${ }^{2}$, Nur $^{3}$, Maya Malinda ${ }^{4}$, Andre Sunjaya ${ }^{5}$ \\ ${ }^{1}$ Program Studi Manajemen, Universitas Kristen Maranatha Bandung \\ Surel: yolla.margaretha@ eco.maranatha.edu \\ ${ }^{2}$ Program Studi Manajemen, Universitas Kristen Maranatha Bandung \\ Surel: asni.harianti@eco.maranatha.edu \\ ${ }^{3}$ Program Studi Manajemen, Universitas Kristen Maranatha Bandung \\ Surel: nur@eco.maranatha.edu \\ ${ }^{4}$ Program Studi Manajemen, Universitas Kristen Maranatha Bandung \\ Surel: maya.malinda@eco.maranatha.edu \\ ${ }^{5}$ Program Studi Manajemen, Universitas Kristen Maranatha Bandung \\ Surel: sunjayaandre_98@yahoo.co.id
}

\begin{abstract}
Community service is one of the pillars of the Tri Dharma of Indonesian Higher Education. Through community service, educators and students can practice science and technology in society. Maranatha Christian University is one of the universities that strives to have an impact on improving the quality of society through community service. Educators specializing in Entrepreneurship and Marketing Management as a part of the Management Study Program, Faculty of Business, Maranatha Christian University, do community service at the Pasundan Rehoboth Temiyang Indramayu Christian Church. This community service activity discussed online marketing strategies for Temiyang's typical products, namely Manisan Si Mayang (candied mangoes by Temiyang) and Temiyang's sandals. In order to get the right target market and products that are widely known, it requires online promotion and marketing. Through online marketing strategy, it is expected to be able to find the right type of online promotion and increase knowledge of online marketing for Temiyang products, so that it can become a strategy in optimizing the marketing of Temiyang's superior products and product that can be reached by the wider customer because they are available online in market place.
\end{abstract}

Keywords: optimalization; online marketing strategy; marketing potential; superior product

\begin{abstract}
ABSTRAK
Abdimas merupakan salah satu pilar dari Tri Dharma Perguruan Tinggi Indonesia. Melalui pengabdian masyarakat (abdimas) tenaga pendidik dan mahasiswa dapat mengamalkan ilmu pengetahuan dan teknologi pada masyarakat. Universitas Kristen Maranatha adalah salah satu perguruan tinggi yang berupaya untuk dapat memberikan dampak bagi peningkatan kualitas masyarakat melalui kegiatan pengabdian kepada masyarakat. Para tenaga pendidik peminatan Kewirausahaan dan Peminatan Manajemen Pemasaran sebagai salah bagian dari Program Studi Manajemen Fakultas Bisnis Universitas Kristen Maranatha melakukan kegiatan pengabdian kepada masyarakat di Gereja Kristen Pasundan Rehoboth Temiyang Indramayu. Kegiatan pengabdian masyarakat ini membahas tentang strategi pemasaran online produk khas Temiyang yaitu Manisan Si Mayang (Manisan Mangga Khas Temiyang) dan sendal Temiyang. Dalam rangka mendapatkan pasar sasaran yang tepat dan produk yang dikenal secara luas maka membutuhkan promosi dan pemasaran online. Dengan metode pelatihan strategi pemasaran online ini diharapkan dapat menemukan jenis promosi online yang tepat dan meningkatkan pengetahuan pemasaran online produk khas Temiyang, sehingga dapat menjadi suatu strategi dalam optimalisasi pemasaran produk unggulan khas Temiyang dan produk khas Temiyang bisa dijangkau oleh masyarakat luas karena tersedia secara online di market place.
\end{abstract}

Kata Kunci: optimalisasi; strategi pemasaran online; potensi pemasaran; produk unggulan

\section{PENDAhULUAN}

Perguruan Tinggi berkontribusi besar dalam peningkatan kualitas hidup masyarakat Indonesia. Perguruan Tinggi berperan besar dalam menyelenggarakan abdimas sesuai dengan UU No 20 Tahun 2003 yaitu tentang Sistem Pendidikan Nasional. Melalui kegiatan pengabdian masyarakat, perguruan tinggi dapat menjadi katalisator tenaga pendidik dan mahasiswanya untuk mengimplementasikan ilmu pengetahuan sehingga berdampak bagi masyarakat. Pengabdian masyarakat merupakan salah satu dari Tri Dharma Perguruan Tinggi, di samping pendidikan dan 
pengajaran serta penelitian. Mahasiswa yang terlibat dalam kegiatan masyarakat akan mendapatkan banyak pengalaman dan pembelajaran yang mengasah karakter mahasiswa. Melalui kegiatan pengabdian masyarakat ini juga mahasiswa mampu menganalisis permasalahan sosial, menemukan potensi dalam masyarakat melalui produk unggulan, mengasah empati dan kepedulian mahasiswa terhadap masyarakat serta mampu menerapkan IPTEKS secara praktikal yang berdampak nyata bagi masyarakat sehingga mereka dapat mandiri dan sejahtera.

Universitas Kristen Maranatha turut serta dalam memberikan pelayanan kepada masyarakat dalam rangka menciptakan masyarakat yang mandiri dan sejahtera. Pengabdian masyarakat ini terselenggara atas kerjasama Peminatan Kewirausahaan dan Peminatan Manajemen Pemasaran Program Studi Manajemen Fakultas Bisnis Universitas Kristen Maranatha dan Gereja Kristen Pasundan Rehoboth (GKP). Di Jawa Barat, terdapat banyak desa yang kurang berkembang karena desa tersebut tergolong rentan akan pengoptimalan produk unggulan desa tersebut. Peran perguruan tinggi diharapkan dapat memberikan strategi pemasaran online yang optimal bagi desadesa yang rentan berkembang. Desa Temiyang merupakan salah satu desa yang berada di Kecamatan Kroya Kabupaten Indramayu Provinsi Jawa Barat. Kegiatan pengabdian masarakat ini adalah bentuk respon dari permintaan Desa Temiyang untuk bisa mengoptimalisasi produk unggulan desa.

Desa Temiyang kaya akan hasil alam yaitu buah mangga, bahkan kualitas mangga Temiyang diakui sebagai salah satu mangga terbaik di Jawa Barat. Pada masa panen, buah mangga yang dihasilkan sangat berlimpah bahkan dapat terbuang dengan sia-sia. Berdasarkan data tersebut maka tenaga pendidikan dan mahasiswa, termotivasi memberikan pelatihan pembuatan manisan mangga sehingga melalui pelatihan tersebut dapat meningkatkan nilai tambah dari buah mangga tersebut. Selain penghasil buah mangga, para ibu Desa Temiyang juga kreatif untuk membuat pernak-pernik khas Temiyang salah satunya adalah sendal etnik yang mereka buat dari bahan sisa pakai. Setelah produk unggulan Desa Temiyang siap dijual maka proses selanjutnya adalah diperlukannya pengetahuan bagaimana strategi pemasaran online dalam rangka optimalisasi pemasaran produk khas Temiyang di pasar digital Indonesia. Produk khas Temiyang ini sebelumnya hanya terbatas dijual kepada rekanan dan masyarakat sekitar dan mereka belum melakukan pemasaran produk secara daring kepada konsumen baik melalui sosial media dan juga melalui market place.

Di era sekarang ini sangat memungkinkan apabila menggunakan pemasaran online sebagai salah satu cara memperkenalkan produk ke pasar melalui promosi secara daring. Pemanfaatan internet tidak hanya untuk kebutuhan pencarian informasi namun juga bisa membantu untuk pemasaran secara online sehingga jangkauan pasar sasaran menjadi lebih luas. Indonesia termasuk salah satu negara dengan pertumbuhan ekonomi internet tercepat di Asia Tenggara. Hal ini menunjukkan bahwa pemasaran melalui media internet juga mengalami peningkatan pertumbuhan yang signifikan. Dalam kegiatan pengabdian masyarakat ini, kami memberikan pelatihan tentang strategi pemasaran online yang merupakan cara yang dapat digunakan di tengah permasalahan pandemi Covid-19. Oleh karena dengan pemasaran online, semua kegiatan promosi dan penjualan dilakukan tanpa tatap muka, sehingga kegiatan tersebut dapat tetap dilakukan walaupun di tengah permasalahan pandemi yang terjadi sekarang. David dan George (2010) pemasaran online adalah pengunaan jaringan internet dan koneksi untuk meraih customer. Teori lain yaitu menurut Kotler dan Keller (2013) internet marketing sebagai proses untuk mempertahankan customer relationship melalui aktivitas online yang melalui pertukaran ide, produk, dan jasa sehingga dapat memenuhi kebutuhan pelanggan. Berdasarkan definisi ini terlihat pada internet marketing terkandung aktivitas yang merupakan transaksi online, baik ide, produk maupun jasa yang pada akhirnya adalah mencapai kepuasan pelanggan. Definisi ini merupakan pengembangan dari definisi marketing yang mencakup hal-hal seperti proses, transaksi, produk, jasa dan kepuasan pelanggan. Menurut Dianawati (2007) pemasaran online adalah bentuk kegiatan komunikasi yang dimana 


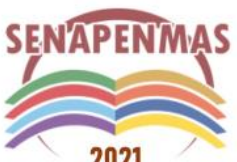

2021
Seminar Nasional Hasil Penelitian dan Pengabdian Kepada Masyarakat 2021 Pengembangan Ekonomi Bangsa Melalui Inovasi Digital Hasil Penelitian dan Pengabdian Kepada Masyarakat Jakarta, 21 Oktober 2021

media yang digunakannya adalah internet. Pemasaran online mencakup luas, tidak hanya mengunakan media website, tetapi juga email dan aplikasi-aplikasi lain yang berjalan di atas protokol internet seperti iklan internet. Diharapkan dengan pelatihan pemasaran online maka akan dapat membuka wawasan dan juga kemampuan dari masyarakat Desa Temiyang dalam melakukan kegiatan pemasaran yang tidak terbatas pada jarak, tempat, waktu maupun kendala-kendala teknis lainnya yaitu melalui pemasaran online (digital marketing). Pengabdian masyarakat ini akan berkontribusi dalam peningkatan perekonomian masyarakat Temiyang karena pasar yang dituju dapat menjadi lebih luas dan tepat sasaran.

\section{METODE PELAKSANAAN PKM}

Strategi pemasaran saat ini tidak cukup lagi apabila hanya dengan metode tradisional saja. Beberapa perusahaan besar dunia telah mengubah strategi pemasaran mereka dari media konvensional ke media digital dan online. Berbagai perusahaan besar di dunia juga sudah memutuskan untuk memanfaatkan internet dan digitalisasi bisnis dengan lebih fokus. Pelatihan dalam pengabdian masyarakat ini akan difokuskan pada pembahasan strategi memanfaatkan strategi pemasaran online menjadi kekuatan dalam metode dan teknik pemasaran dan promosi. Beberapa metode penting seperti $e$-Mail Marketing, pengertian promosi, jenis-jenis promosi dan pemasaran online (marketing online) dan metode $e$-Marketing lain akan dibahas secara konkrit, detail dan runut disertai contoh kasus. Pelatihan ini juga dilengkapi oleh presentasi mengenai informasi dan pemrosesan informasi mengenai strategi pemasaran online oleh karena tujuan pelatihan yang dilakukan terkait dengan pelatihan tentang strategi pemasaran online. Strategi pemasaran online ini dapat dilakukan sebagai cara yang dapat digunakan untuk meningkatkan kegiatan promosi dan penjualan dari produk khas Temiyang.

Adapun pemaparan materi yaitu pemasaran online (e-commerce) yang dimana penggunaan internet sebagai media penjualan barang dan jasa. Pemasaran melalui media internet memungkinkan suatu usaha untuk memperluas pasar sasaran. Di dalam strategi pemasaran online yang terpenting adalah mengetahui secara mengenai konten pemasaran bagaimana cara membuat konten pemasaran. Setelah sesi pemaparan materi maka sesi berikutnya adalah sesi diskusi seputar jenis promosi yang tepat sesuai target market, juga mengenai strategi pemasaran online untuk produk Manisan Si Mayang (manisan mangga khas Temiyang) dan sendal etnik khas Temiyang.

\section{HASIL DAN PEMBAHASAN}

Kegiatan pengabdian masyarakat ini juga merupakan kelanjutan dari kegiatan pengabdian masyarakat sebelumnya dalam rangka optimalisasi potensi produk unggulan khas Temiyang yaitu Manisan Si Mayang (manisan mangga khas Temiyang) dan sendal etnik khas Temiyang. Peraturan PPKM (Pemberlakuan Pembatasan Kegiatan Masyarakat) dari pemerintah yang membatasi kegiatan yang melibatkan kerumunan orang ini tidak dapat dilaksanakan secara langsung di Desa Temiyang. Oleh sebab itu kegiatan pengabdian masyarakat ini dilaksanakan melalui penggunaan meeting room secara daring. Kendati demikian, antusiasme para peserta pelatihan sangat baik dan dapat berinteraksi dengan baik dengan para fasilitator. Kegiatan pengabdian masyarakat ini dilakukan sesuai kebutuhan dari apa yang terjadi saat ini pada pandemi Covid 19, dimana kegiatan promosi maupun penjualan lebih banyak dan efektif dilakukan secara online. Adapun kegiatan pengabdian masyarakat ini diimplementasikan dalam bentuk pelatihan dengan tema yang diambil adalah tentang strategi pemasaran online. Pemasaran online atau lebih dikenal dengan pemasaran digital (Digital Marketing) merupakan pilihan jalur yang tepat di era sekarang ini. Pemilihan jalur pemasaran yang tepat tentunya berpengaruh terhadap perkembangan bisnisnya. Apalagi semua support system yang mendukung pemasaran online di era serba digital sekarang ini. Pemasaran online dianggap mampu melebarkan sayap pemasaran bisnis secara optimal dengan biaya yang jauh lebih ringan dibandingkan secara offline. Terdapat pemaparan 
materi yang dilakukan oleh Bapak Allen Kristawan, S.E., M.M. Berikut adalah dokumentasi kegiatan pada saat pemaparan materi dapat dilihat pada Gambar 1 berikut.

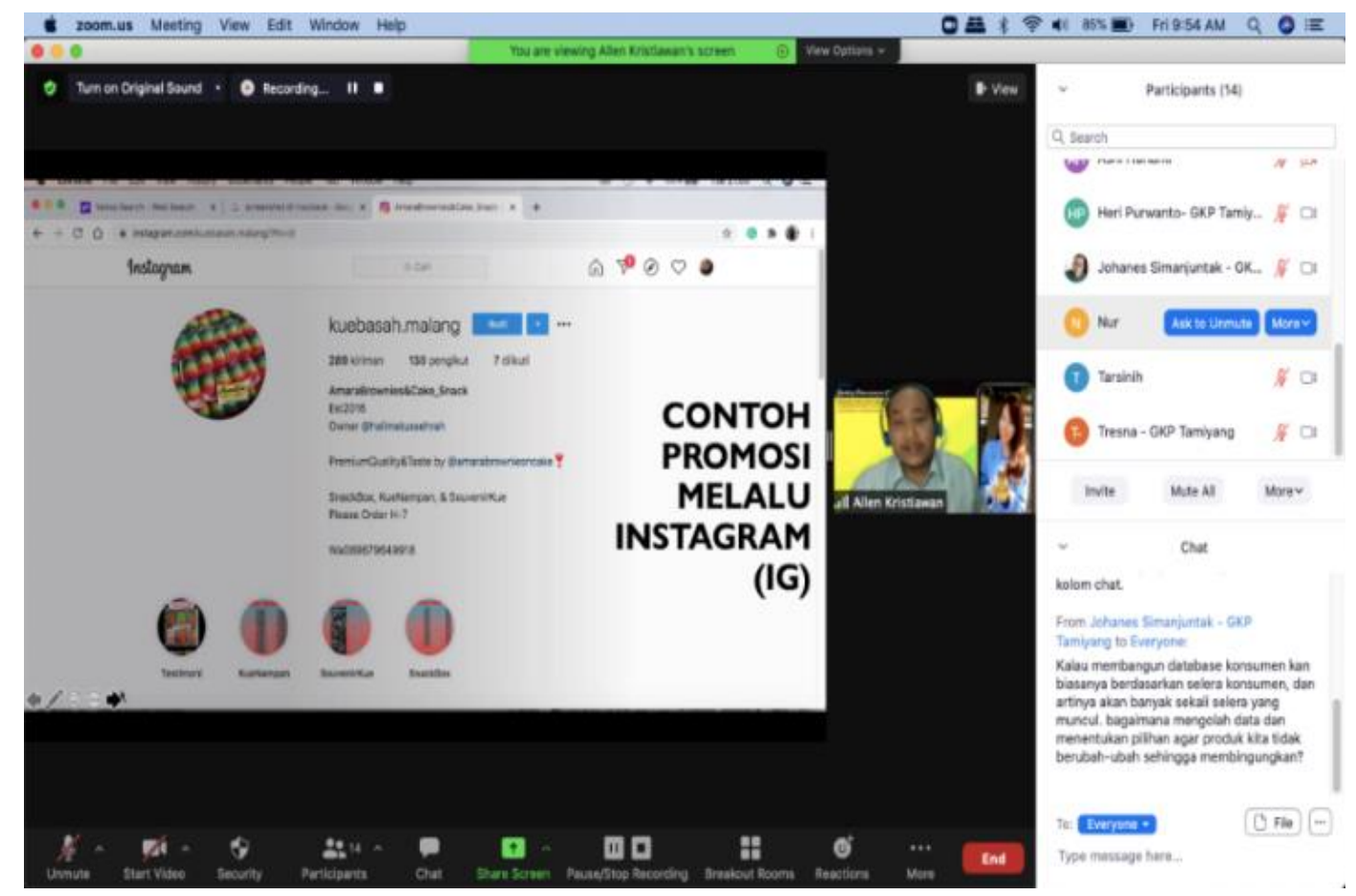

Gambar 1. Pemaparan Materi Strategi Pemasaran Online

Pemaparan yang dilakukan oleh Bapak Allen Kristiawan, S.E., M.M. adalah seputar pemasaran online. Beliau menjelaskan pemasaran online adalah salah satu strategi pemasaran yang memanfaatkan media internet sebagai alat dalam aktivitas pemasarannya. Media yang digunakan adalah internet, media sosial, fasilitas digital bahkan augmented reality. Hal ini dapat dilakukan dengan iklan, konten dan postingan melalui media sosial. Selanjutnya dijelaskan juga mengenai strategi untuk pemasaran online, diantaranya: membangun database konsumen, berorientasi pada konsumen, contoh website, membuat konten pemasaran, melakukan pemasaran melalui media sosial, melakukan kerjasama dengan influencer, membuat email pemasaran, memanfaatkan afiliasi pemasaran. Secara spesifik dijelaskan mengenai bagaimana membuat konten pemasaran. Konten pemasaran adalah format pemasaran apa pun yang berisi pembuatan dan berbagi konten media dan publikasi untuk memperoleh pelanggan dan banyak audiens. Inti dalam pembuatan konten pemasaran adalah Buat, Sebarkan, Bagikan, dan Tumbuhkan. Penjelasan juga disertai dengan contoh-contoh promosi melalui media sosial di antaranya contoh promosi melalui Facebook, contoh promosi melalui Whatsapp, dan contoh promosi melalui Instagram.

Di dalam digital marketing terdapat commercial online channel (saluran online commercial). Dalam hal ini UMKM atau perusahaan membuat informasi secara online yang dapat diakses oleh pengguna. Saluran online ini memberikan layanan bagi pelanggan seperti informasi (surat kabar, perpustakaan, pendidikan, perjalanan olahraga, dan referensi), hiburan, jasa pembelanjaan, kesempatan berdialog (bulletin bords, forum, chat boxes) dan email. Kedua adalah internet yang merupakan jaringan global yang terdiri dari banyak sekali jaringan. Ketiga adalah komputer yang memungkinkan komunikasi global yang terdesentralisasi. Dalam dunia usaha saat ini internet merupakan kebutuhan pokok, terutama bagi penduduk kota besar maupun kalangan dunia usaha dunia bisnis bahkan akademis. Menurut Kotler dan Keller (2013) pemasaran online sangat banyak manfaatnya baik bagi pelanggan dan bagi para para pemasar itu sendiri, diantara manfaat bagi para 
pelanggan itu adalah layanan kepraktisan dan kemudahan. Para customer memungkinkan melakukan pemesanan produk kapan saja dan dimana saja mereka berada. Pelanggan tidak harus pergi ke toko atau tempat usaha para perusahaan berjualan. Kedua adalah Informasi. Para pelanggan dapat memeroleh segudang informasi tentang perusahaan, produk, dan pesaing dengan sangat mudah dan dengan data yang valid. Ketiga adalah meminimalisasi tawaran marketing yang kadangkala cenderung mengejar dan merongrong pelanggan. Keempat pembeli dapat memesan barang sesuai dengan keinginan mereka. Pembeli dapat langsung mengkomunikasikan keinginan mereka kepada perusahan atas barang atau jasa yang mereka butuhkan, sehingga pembeli dapat mengetahui kelebihan serta kekurangan dari produk tersebut.

Sedangkan manfaat dari digital marketing bagi para pemasar yaitu adaptif yang cepat dengan kondisi pasar yang hypercompetitive. UMKM dapat dengan cepat memungkinkan menambah produk, mengubah harga dan mengubah deskripsikan produknya pada laman digital marketing. Kedua adalah faktor biaya yang jauh lebih rendah. Para pemasar online dapat menghindari biaya pengelolaan toko dan biaya sewa, asuransi, serta prasarana dan biaya overhead lain yang menyertainya. Pemasar juga dapat membuat katalog digital dengan biaya yang jauh lebih rendah daripada biaya percetakan untuk pembuatan katalog produk secara fisik. Ketiga adalah mempermudah menjalin hubungan dengan calon pelanggan dan pelanggan melalui layanan dan service 24 jam melalui layanan interaksi pelanggan. Keempat adalah pengukur besaran market share. Para pemasar dapat mengetahui beberapa banyak orang yang mengunjungi situs online para pemasar.

Sesi setelah pemaparan materi adalah tanya jawab dan diskusi yang dimoderasi oleh fasilitator yang terdiri dari para mahasiswa dan tenaga tendidik Fakultas Bisnis Universitas Kristen Maranatha. Dalam sesi tanya jawab dan diskusi ini juga, terdapat beberapa pertanyaan dari pihak Temiyang mengenai strategi pemasaran online yang bisa diimplementasikan sebagai langkah awal dalam pemasaran produk khas Temiyang. Selain itu juga terdapat pembahasan seputar jenis promosi yang tepat dan sesuai dengan target pasar produk unggulan Temiyang. Kuswoyo (2020) mengemukakan analisisnya mengenai target pasar produk tersebut lebih ke usia antara 20-35 dan berjenis kelamin perempuan, dan gemar mengonsumsi manisan buah dan menyukai pernak-pernik. Adapun jenis media promosi yang cocok untuk target tersebut adalah periklanan, promosi penjualan, dan penjualan langsung. Media sosial yang digunakan dalam promosi produk khas Temiyang adalah instragram dan whatsapp karena disesuaikan dengan target pasar yang dituju. Dalam kegiatan diskusi dan tanya jawab, fasilitator juga memberikan stimulus berupa hadiah agar memberikan semangat sekaligus mengonfirmasi sejauh apa masyarakat bisa memahami setiap pengetahuan dan pelatihan yang diberikan. Berikut adalah dokumentasi pada saat sesi tanya jawab dan diskusi yang dipimpin oleh Bapak Allen Kristiawan, S.E., M.M. 


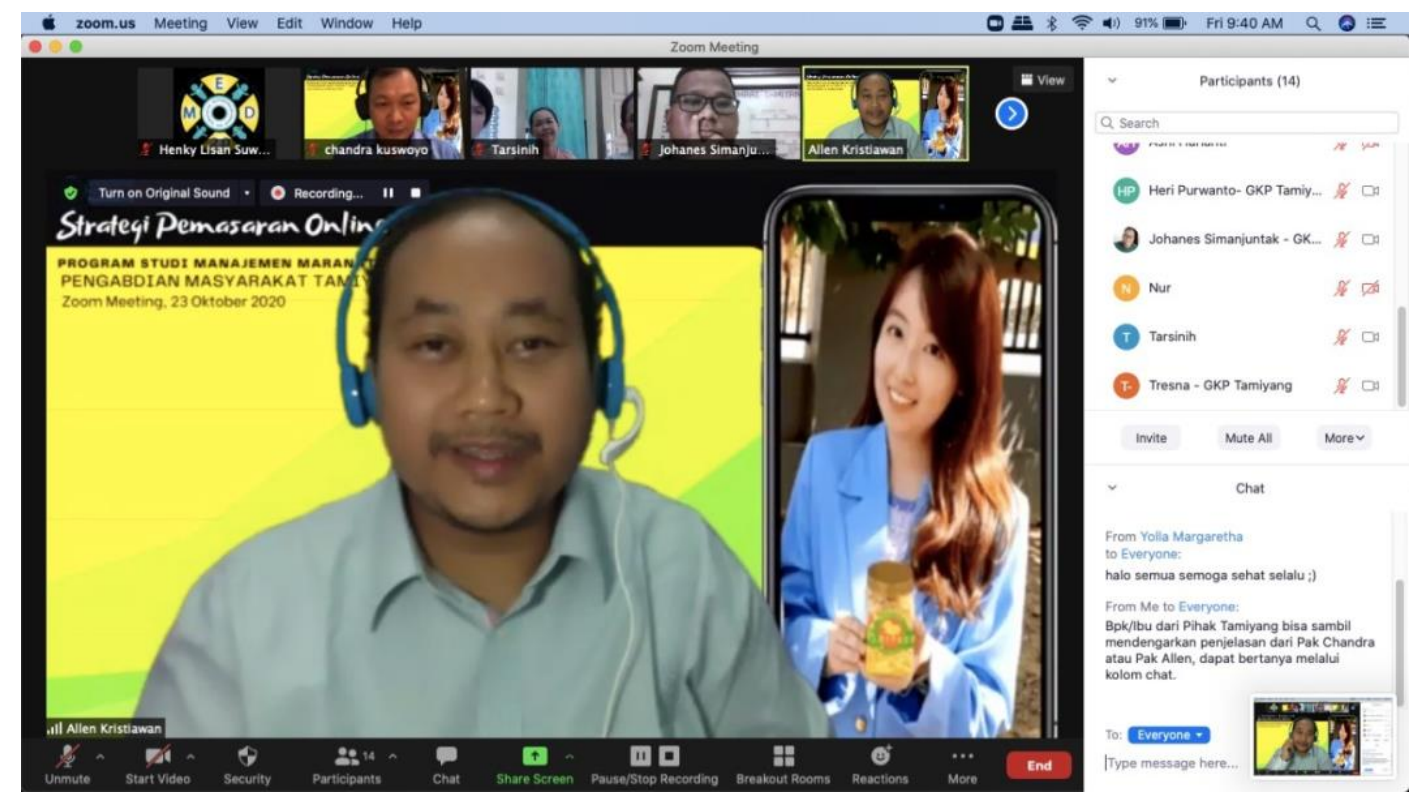

Gambar 2. Tanya Jawab dan Diskusi Strategi Pemasaran Online

\section{KESIMPULAN DAN SARAN}

Setelah pelatihan strategi pemasaran online, masyarakat Temiyang menjadi melek teknologi dan memiliki pengetahuan lebih untuk melakukan pemasaran daring produk khas Temiyang. Mereka akang menggunakan sosial media seperti Instagram dan Whatsapp group sebagai wadah promosi dan penjualan. Melalui pengabdian masyarakat ini dapat meningkatkan optimalisasi potensi produk unggulan Desa Temiyang karena melalui pelatihan tentang strategi pemasaran online memberikan ilmu pengetahuan dan keterampilan juga kompetensi yang bagi masyarakat Temiyang dalam implementasi strategi pemasaran online. Dimana perkembangan zaman yang saat ini mayoritas beralih ke dalam kegiatan pemasaran online, selain itu juga sebagai cara untuk bisa bersaing di pasar yang sangat kompetitif dan sangat dinamis. Melalui strategi pemasaran online yang tepat maka masyarakat Temiyang perusahaan untuk beradaptasi dengan kebutuhan pelanggan yang cenderung sekarang ke dunia online, mengurangi biaya transaksi manual, dan memungkinkan pelanggan terjangkau secara luas dan dimana saja tanpa batasan tempat dan waktu. Kristiawan (2020) memaparkan bahwa pemasaran produk khas Temiyang secara online akan berdampak yaitu peningkatan segmentasi. Dengan adanya pemasaran online akan memperluas segmentasi hal ini disebabkan karena jangkauan pasar yang juga akan semakin luas. Kedua adalah mengembangkan strategi pemasaran lebih cepat dan tepat dalam cycle time, dengan adanya alur perputaran waktu yang lebih cepat dan mudah maka strategi pemasaran dapat sangat agresif dan adaptif dalam menghadapi perubahan pasar. Ketiga adalah peningkatan inovasi perusahaan karena untuk dapat bersaing dan bertahan dalam persaingan bisnis maka perusahaan harus senantiasa melakukan berbagai strategi inovasi pemasaran yang tepat sasaran.

Namun mendapatkan hasil yang lebih efektif maka pelatihan strategi pemasaran online ini tentu saja perlu disertai dengan kegiatan selanjutnya yaitu kegiatan pendampingan dan coaching, agar pemasaran online yang dilakukan oleh masyarakat Temiyang juga dapat lebih tepat guna dan tepat sasaran sehingga produk unggulan Desa Temiyang dan semakin luas dikenal oleh pasar dan mendapatkan market share yang signifikan. Dengan demikian dapat meningkatkan pertumbuhan perekonomian desa melalui produk unggulan khas daerah Desa Temiyang. 


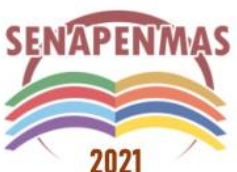

2021
Seminar Nasional Hasil Penelitian dan Pengabdian Kepada Masyarakat 2021 Pengembangan Ekonomi Bangsa Melalui Inovasi Digital Hasil Penelitian dan Pengabdian Kepada Masyarakat Jakarta, 21 Oktober 2021

Ucapan Terima Kasih (Acknowledgement)

Pengabdian masyarakat ini terselenggara dengan baik atas dukungan berbagai pihak. Kami mengucapkan terima kasih kepada masyarakat Desa Temiyang dan Gereja Kristen Pasundan Rehoboth Temiyang. Kami juga mengucapkan terima kasih kepada Lembaga Penelitian dan Pengabdian Masyarakat dan Fakultas Bisnis Universitas Kristen Maranatha yang telah membantu dalam hal dukungan baik materiil maupun non-materiil, sehingga acara kegiatan pengabdian masyarakat ini bisa berjalan dengan baik.

\section{REFERENSI}

Dessler Garry. (2008). Human Resource Management, fourth edition, New Jersey: Prentice Hall Internasional.

Dianawati, Ajen. (2007). Enam Rahasia Sukses Menjadi Jutawan Internet, cetakan 1. Jakarta: Media Kita.

Kuswoyo, C. (2020). Pemasaran. Materi Pengabdian Masyarakat Tamiyang 23 Oktober 2020. Tidak dipublikasikan.

Kristiawan, A. (2020). Pemasaran Online (Online Marketing). Materi Pengabdian Masyarakat Tamiyang 23 Oktober 2020. Tidak dipublikasikan.

Kotler, Philip \& Keller, Kevin Lane. (2013). Marketing Management (14thEdition). England: Pearson Education. 
Seminar Nasional Hasil Penelitian dan Pengabdian Kepada Masyarakat 2021

Pengembangan Ekonomi Bangsa Melalui Inovasi Digital Hasil Penelitian dan

Pengabdian Kepada Masyarakat

Jakarta, 21 Oktober 2021

(halaman kosong) 